DOI: $10.2478 /$ pof-2018-0024

VOLUME 10, ISSUE 2, 2018

ISSN: 2036-5438

\title{
Bicameralism in Belgium: the dismantlement of the
} Senate for the sake of multinational confederalism

by

Patricia Popelier*

Perspectives on Federalism, Vol. 10, issue 2, 2018 


\section{Abstract}

Belgium was established in 1830 as a unitary state with a bicameral parliament, with symmetrical powers for the upper and the lower house. While federalism and bicameralism are often considered a pair, the Belgian system shows an inverse relationship. The Senate gradually turned into a house representative of the sub-states, but its powers declined inversely proportional to the level of decentralisation of the Belgian state. This paper inquires how the dismantling of the Belgian Senate fits in the increasingly devolutionary nature of the Belgian state structure. First, it nuances the link between bicameralism and federalism: bicameralism is an institutional device for federalism, but not by necessity, and only under specific conditions. The official narrative is that the Belgian Senate was reformed to turn it into a house of the sub-states in line as a federal principle, but in reality the conditions to fulfil this task are not fulfilled. Instead, the paper holds that bicameralism in Belgium is subordinate to the needs of multinational conflict management, and that complying with the federative ideal of an upper house giving voice to the collective needs of the sub-states would stand in the way of the evolution of the Belgian system towards confederalism based on two major linguistic groups.

\section{Key-words}

Bicameralism, parliamentary systems, federalism, confederalism, multinationalism 
Even before its establishment, when Belgium's founders discussed the design of the new Belgian State, the upper chamber was highly contentious in Belgium. While the National Congress was like-minded on most issues to be dealt with in the new constitution, the choice of unicameralism or bicameralism was subject of intense debate (Huyttens 1844: 412-501). This discussion has never faded over time, leading to multiple reforms. The most fundamental reforms took place in 1993 and 2012. The common thread in both reforms was the narrative of sub-state representation combined with declining powers inversely proportional to the level of decentralisation of the Belgian state. Considering that federalism and bicameralism are often considered a pair, the research question is how the dismantling of the Belgian Senate fits in the increasingly devolutionary nature of the Belgian state structure. In this paper the Belgian case is used as an illustration for a more general proposition on the relevance of bicameralism for multi-tiered systems. The proposition is twofold: first, it states that bicameralism is an institutional device for federalism, but not by necessity, and only under specific conditions; second, it holds that in multinational states, bicameralism is subordinate to the needs of multinational conflict management.

The paper is structured as follows. The first section gives an overview of the Belgian Senate throughout history, with emphasis on the 1993 and 2012-2014 reforms. The second section substantiates the proposition by listing the functions of bicameralism in multitiered systems. The third section returns to the Belgian case, explaining Belgium's characteristics in the light of the theoretical findings.

\section{An overview of the evolution of the Belgian Senate}

\subsection{Origins: the Senate in a unitary state}

The constitution that gave birth to the Belgian State established bicameralism in a unitary state structure. Opponents argued for unicameralism as symbol of national unity and equality (Huyttens 1844: 458-459). The same argument underpinned the choice for unicameralism in Finland, Norway and Iceland and initially also France (Mastias and Grange 1987: 460; 218). However, historical, societal and political context favoured the 
choice for an upper chamber. Historically, Belgium was already familiar with bicameralism: it was an institutional feature of the Unitary Kingdom of the Netherlands, from which the Belgians had seceded (Bécane in Mastias and Grange 1987: 367; De Schepper 1990: 16-31). In the societal context, the constitution had, admittedly, abolished class distinctions, but in reality the population was composed of several strata on top of which were the aristocracy and the bourgeoisie. The National Congress rejected the British model of a hereditary aristocratic upper chamber, but as a result of the elevated levy condition the aristocracy was well represented in the newly elected Senate (Luyckx and Platel 1985, 5-6). From a political perspective, the Senate was the result of a compromise between progressive forces and more conservative ones. Belgium was not unique in this respect: the transition to liberal democracy in the nineteenth century was a key moment for bicameralism (Mastias and Grange 1987: 44-45), a lubricant for helping the old elite to accept the assumption of power by a new political class (Bécane in Mastias and Grange 1987: 151). In Belgium, another argument played a part: to gain international recognition a conservative touch was important to reassure the Great Powers (Alen 1992: 439-440; Stengers 1990: 11-12).

Initially, the functions of the Belgian Senate were threefold. It was to serve as a counterpower for the political powers of the 'progressive' Chamber of Representatives, a forum for reflection, and it secured the representation of large landowners and aristocracy (Alen 1992: 441; Goossens 1983: 795). These functions determined the Senate's composition and powers. Conditions of age and fortune secured the conservative element. ${ }^{\mathrm{I}}$ Symmetrical bicameralism, giving the Senate nearly the same powers as the Chamber of Representatives, made sure that its objections would not pass unnoticed.

As in other countries, the rise of democracy plunged the Senate into a crisis. The dilemma was that the upper chamber's role as protector of elite interests and institutional check on the quality of legislation presupposed specificity in composition, but deprived it of democratic legitimacy and therefore of authority (Mastias and Grangé 1987: 51-74). In Belgium, the Senate evolved from specific but not legitimate into legitimate but not specific. In a first period, the aristocratic Senate played second fiddle; in a second period the Senate was gradually reformed to give it more legitimacy (Goossens 1983: 796). The entrance of political parties and party discipline eliminated whatever specificity that remained, making the Senate redundant. In small unitary states such as Sweden, Denmark and Croatia, unicameralism was a reply to the dilemma of upper chambers (see Massicotte 
2001: 155-156). In Belgium, federalism rescued the upper house from abolishment. Indeed, the dilemma is solved when territorial division enables the combination of specificity and legitimacy. This explains why, world-wide, federalism appears as one of the dominant variables correlated with bicameralism (Massicotte 2001:152). ${ }^{\text {II }}$

\subsection{The fourth state reform: The Senate in a federal state}

The fourth state reform in 1993 offered an opportunity to deal with the Senate, which was increasingly criticised for being redundant and time-consuming. Ultimately, the Senate was not abolished but drastically reformed with its powers curtailed. Since 1970, Belgium, initially a unitary system, gradually devolved, culminating, in 1993, in the official recognition in Article 1 of the Constitution of the federal state. By that point the sub-state Communities had already been established, and for the first time their Parliaments would be composed of directly elected representatives. This made it possible to reduce the number of seats in the Senate without losing political mandates. At the same time, federalism was invoked to justify the Senate's preservation. After all, federalism and bicameralism seem a natural pair.

Nevertheless, the Senate was not reformed into a chamber of the sub-states. Instead, it was called a 'meeting point' between the federal authority and the sub-states - in Belgium: the Communities and Regions. Moreover, the Senate was to maintain its function of a place for reflection. The Chamber of Representatives was to be the assembly for the daily legislative work, and the exclusive political chamber. The Senate was deprived of the power to control the Government. The result was a hybrid chamber, complex in its composition and powers.

The Senate was composed of four types of senators. The directly elected senators and the Community senators fulfilled the function of 'meeting room': the first were to represent the federal interests, the latter, appointed by the Community Parliaments from within their members, the regional interests. The co-opted senators, appointed by the former categories, were to bring in specific expertise for the reflective function. The last category was a throwback to the past: the King's children were senators by right. Except for the last category, the Senators, as the MPs in the Chamber of Representatives, were divided in two language groups, French and Dutch. The German Community Senator, however, is not part of a language group. 
In establishing parliamentary functions, three law making procedures were put in place. According to the default procedure, the Chamber of Representatives became the dominant legislative assembly. In its role as a chamber of reflection, the Senate could decide whether to discuss a bill adopted by the Chamber of Representatives, and it retained the right of initiative. It could, however, only suggest amendments; the Chamber had the final say. For specific matters, listed in Art. 77 of the Constitution, the Chamber and the Senate remained symmetrical, implying that every bill had to be adopted by both. These were mostly matters linked to the institutional design of the federal state, in line with the Senate's function as 'meeting place'. Finally, Article 74 of the Constitution listed four types of laws in which the Senate had no say at all. These were laws that were closely linked to the Chamber's political function: the civil and criminal liability of the federal Ministers, the federal budget, the granting of naturalisation and the setting of army quotas.

Criticism, however, remained, as the Senate was unable to fulfil its functions. First, it did not perform as a meeting place, because the directly elected Senators outnumbered the Community Senators, 40 to 21. Moreover, Community Senators, appointed on the basis of the results of the federal elections, did not necessarily reflect the majority in the Community Parliament. In addition, the Regions were only indirectly represented, often without a seat for the Dutch-speaking representatives of the Brussels Region. The linguistic communities, on the other hand, were well represented through their language groups, but the Senate was redundant for this purpose, as the House was already divided into language groups. Second, the lack of specificity hindered the Senate in its function as a reflection room. The Chamber of Representatives and the Senate were still made up of the same political majorities, due to the fact that they were elected on the same day and the Community Senator's seats were allocated on the basis of federal election results. Moreover, no guarantees were built in to avoid that co-option would become a second chance for failed election candidates rather than a mechanism to bring in specific expertise from people outside of the political domain. On top of that, the complexity of law making procedures created uncertainty, especially in respect of 'mixed' bills, containing matters allotted to different procedures.

Consequently, pleas for the abolishment of the Senate re-emerged. In a political agreement of 26 April 2002, it was ultimately decided not to abolish the Senate, but to 
reform it into a genuine 'chamber of the sub-states'; but it took another decade to actually reform the Senate in that way.

\subsection{The sixth state reform: the Senate in a (con)federal state}

The sixth state reform was implemented after a long political crisis. After the elections in 2010, it took a year and a half of negotiations before the political parties agreed on a coalition agreement including, on request of the Flemish parties, a new phase in the state's devolution, with more competences being transferred to the sub-states. Considering the widespread criticism of the hybrid Senate as a consequence of the fourth state reform, the opportunity was seized to tackle the problem and turn the Senate into a Chamber of the sub-states, with effect after the 2014 elections.

\section{Composition}

The Senate is now composed of 60 Senators. Its composition, however, is still complex; the Senate still consists of French and Dutch language groups, and the representation of sub-states must not influence their relative strengths. This means that the representatives of the bilingual Brussels Region must be spread over two language groups. The Flemish Community and the Flemish Region have merged, with only one Parliament represented. On the francophone side, however, the French Community and the Walloon Region are different entities with different Parliaments. As a result, 29 Senators are designated from the Flemish Parliament or the Dutch language group of the Brussels Region. One of them must have residence in Brussels. Ten are designated by the Parliament of the French Community, at least nine of which are members of this Parliament. Three must be members of the French language group of the Brussels Parliament. Eight are designated by and from the Walloon Parliament. Two are designated by and from the French language group of the Brussels Parliament. One is designated by and from the Parliament of the German-speaking Community and does not belong to a language group in the Senate.

In addition, ten senators are still co-opted. Their presence is at odds with the logic of a sub-state chamber, especially since the seats are distributed on the basis of the results of federal elections. The ratio is purely political. The state reform included the splitting of the electoral district Brussels-Halle-Vilvoorde. This was the only electoral district that crossed 
linguistic borders, with mutual benefits for the Flemish and the French-speaking political parties. The first were able to gain seats in the federal Parliament for Flemish candidates in Brussels, as the votes in the Flemish districts Halle-Vilvoorde were added to the few Flemish votes in Brussels. The latter were able to reach out to the French-speaking voters residing in the Flemish districts. For that reason, however, the Flemish parties considered the district a symbol of French imperialism and requested the splitting of the district. As a compensation, the francophone candidates in Flemish municipalities and the Flemish candidates in Brussels could be considered for co-option to the Senate. In practice, the cooption system, as discussed before, gives failed candidates a second chance, irrespective of their home district.

Finally, gender quotas were introduced (Art. 67 \ 3 Constitution). Gender quotas already applied to the lists of candidates for elections, raising the proportion of women in Parliament from 10 to almost 40 \% (see Popelier and Lemmens 2015: 112-113). As the category of directly elected Senators was removed, a system was put in place reserving one third of the seats for each gender. In 2014 this resulted in perfect gender parity, with a 50\% representation of each sex. The question remains as to why this gender quota is deemed relevant for the Senate. The quota for the lists of candidates secures an equal starting position for men and women, by compensating for the alleged unconscious mechanisms that put women behind. Quotas for the actual seats, however, impact on the outcome rather than the starting position. The Senate is a chamber that is presumed to protect the interests of the sub-states, not women (or men) - especially since the Senate is not involved in the adoption of gender-related legislation.

\section{Competences}

While the Senate became a (more or less) genuine chamber of the sub-states, its powers, however, were drastically reduced. It is constructed as a non-permanent body (Art. 44 Const.), and as a rule does not intervene in the law-making procedure; only in two categories of laws does the Senate still have a say. In the first, in the types of laws listed in Art. 77 of the Constitution, the Senate has the same powers as the Chamber of Representatives. These laws concern the Constitution itself as well as matters that directly affect the federal state structure and the statute and functioning of the Communities and Regions, including the organisation of the Constitutional Court. In the second, in the types 
of laws listed in Art. 78 of the Constitution, the Senate has the right to discuss bills approved by the Chamber of Representative and to propose amendments, but it has no right of initiative and the Chamber has the final say. These laws mainly concern institutional matters too, such as the procedure for the avoidance of conflicts of interest, and the prevention of discrimination on ideological and philosophical grounds - which, in Belgium, largely coincide with the linguistic fault lines - or the organisation of the Council of State or administrative courts.

Daily legislative work is handled by the Chamber of Representatives to the exclusion of the Senate. Even laws that fall under the rare category of shared powers are not listed under Art. 77 or 78 of the Constitution, and are therefore adopted without the Senate's involvement. Tax laws, for example, are concurrent matters, with priority for federal tax laws: sub-states have taxing powers, but they cannot tax matters that are already subjected to federal taxes, and federal laws can determine exceptions to regional taxes (Art. 170, $\mathbb{} 2$ Const.). The Senate does have a non-decisive say in laws that interfere in sub-state tax laws (Art. 78, $\$ 2$ Const.), though not in regular tax laws, although they determine the room that is left for regional taxes. Framework matters, for example regarding public procurement or consumer protection, are also outside the scope of the Senate's powers. The same goes for the few matters in which the federal legislature lays down the normative framework and the Regions have executive powers. For example, the normative framework regarding unemployment policy is a federal matter, but the Regions have the power to check whether the unemployed are available for work and if necessary to sanction them. Equally striking is that the Senate only has a limited say, through Art. 78 Constitution, in the organisation of the Council of State. Yet, the Council of State has important powers that also concern the sub-states: it can annul executive regulations and orders, and executives are under the obligation of submitting legislative bills and draft executive regulations to the Council for legal advice.

As to external relations, the Senate has been deprived of its privileged function. Whereas the 1993 reform obliged the government to ask the Senate for approval before submitting a treaty to the Chamber of Representatives, the Senate no longer has any power in these matters. Its main function in external relations is to act as an intermediary for reasoned subsidiarity opinions of sub-states, because EU Protocol No 2 on Subsidiarity 
and Proportionality distributes votes of Member States on these matters between both houses in bicameral systems (see Popelier and Vandenbruwaene 2011: 216-226).

\subsection{Conclusion}

Two decades after Belgium was declared a federal state, the Senate has finally transformed into a House of the sub-states. This, however, has proven to be a disguise for the simultaneous dismantlement of bicameralism.

In its present form, the Senate comes to life mainly for constitutional revisions and at key moments in the transformation of the federal state structure. In between, it makes a pretence of purpose by producing well-elaborated study reports, called information reports', on federal issues that also have repercussions on the competences of the Communities or Regions (Art. 56 Constitution). Between 2014-2017, eight information reports were adopted on a variety of matters such as surrogate motherhood, gender equality, child poverty, and the implementation of EU law, resulting in recommendations for which follow-up is in no way guaranteed. In addition, in the same period, the Senate adopted one constitutional revision and two laws following the symmetrical bicameral procedure of Art. 77 Constitution, and it discussed (without proposing amendments) three out of 15 laws that came within the asymmetrical bicameral procedure of Art. 78 Constitution. Further, it adopted six amendments of the Senate's procedural rules, and eight non-binding resolutions. Meanwhile, the Chamber of Representatives adopted 511 laws and one constitutional revision.

Evidently, the gradual federalisation of Belgium is coupled with the simultaneous gradual dismantling of the Senate. This is puzzling, as federalism and bicameralism are usually a pair. The question, then, is why we observe these opposing movements at play.

\section{The functions of Upper Houses in multi-tiered systems}

Multi-tiered systems come in many forms. What they have in common, is that they deal with tensions between territorial sub-entities' claims for autonomy on the one hand, and on the other the concern for the state's integrity as a whole. In a dynamic approach to federalism, forms of state are no longer categorised by defining sets of institutional features. For example, bicameralism is one of several determinants but not a defining 
feature of federal systems; and confederal systems are not necessarily composed of sovereign states. Instead, multi-tiered systems are situated (and evolve) on a sliding scale based on parameters that measure the autonomy of the sub-states as well as the integrity of the federal state as a whole. Federal constructions aim at a balanced relation between diversity and integrity, whereas in so-called regionalised or quasi-federal states the concern for integrity gains the upper hand, and confederal systems primarily aim at securing subentities' autonomy (see further Popelier 2014:5-6).

Bicameralism has a clear purpose, wherever central decisions are adopted that impact upon the sub-entities: it allows sub-states to protect their interests (2.1.). Closely linked to this is the representation of sub-state's interests in external relations (2.2.). In more traditional federal states the idea of checks and balances is also part of an Upper House's rationale (2.3.). In multinational states, much revolves around multinational conflict management (2.4.). In essence, however, bicameralism is a device for federal systems that seek a balance between diversity and integrity, as the Upper House secures the interests of the sub-states through a collective veto right while committing them to the federal interest in daily legislative work. This is not necessarily considered the perfect solution in multitiered systems with a more pronounced emphasis on either integrity or diversity.

\subsection{Territorial representation}

\section{Function}

The most obvious function of Upper Houses is that of an institutional mechanism to voice the interests of sub-national entities. Bicameralism is a balanced solution to this end, securing both differentiation and integration. On the one hand, it allows sub-states to protect their interests at the central level, on the other hand, by involving sub-state representatives in everyday central law-making, these representatives are more likely to appreciate the central perspective. For this reason, federalism and bicameralism seem a perfect pair, to the point that Upper Houses have been labelled 'identity bracelets' for federal systems (Burgess 2006: 204).

In practice, it proves difficult to maintain a perfect balance, and some scholars doubt whether Upper Houses are ever able to secure both national integrity and sub-state autonomy (Sharman 1987: 189). Involving sub-state representatives too systematically in 
central law-making bears the risk that they start to sympathise more with the central authorities rather than their sub-states (Osoghae 1998: 219-220), especially if they have to give account to central party leaders (Palermo and Kössler 2017: 142; Swenden 2010: 114117).

Moreover, Upper Houses in federal systems are not necessarily designed to give voice to the interests of the sub-states, or to do so in an adequate way. The necessary conditions to fulfil this function adequately implicate both the composition and the powers of the Upper House. Russell adds to this that Upper Houses must be perceived as legitimate (Russell 2000: 42; 250-254).

\section{Conditions}

In the absence of an institutional link, for example if the Upper House is composed through direct elections, this House will protect the interests of electors in a region, rather than the interests of the sub-state government (Watts 2003: 78). The political system also plays a part: whether a chamber of the sub-states is strong or weak, usually correlates with the presidential or parliamentary character of the system (Swenden 2010: 106). In most parliamentary systems, where the federal executive emanates from the Parliament, party politics and executive dominance hinder the effective protection of sub-state interests through the Upper House (Bogdanor 1992: 415-416). In these systems, effective protection is much better secured at the executive level (Sharman 1987: 82) or through executive representation in the Upper Chamber, as is the case in the German Bundesrat (Watts 2003: 78).

As to competences, it is not necessary to give the Upper House equal powers in all matters submitted before Parliament. It is, in particular, unnecessary for an Upper House to be involved in the adoption of laws regarding matters that range within the federal state's sphere of exclusive competences (Swenden 2010: 112). On the contrary, as was mentioned before, this may even have the reverse effect, if it results in sub-state representatives sympathising chiefly with federal interests. Differentiation, then, is an obvious feature of Upper Houses designed to voice the interests of territorial sub-states. In theory, a distinction can be made between four categories of subject-matters: (1) matters directly affecting the federal organisation and the statute and functioning of the sub-states; (2) matters that influence the sub-state's space for policy-making, e.g. with regard to shared 
powers - concurrent as well as framework legislation - or, in the case of executive federalism, legislation that is implemented by the sub-states; (3) matters that indirectly affect sub-state policy and (4) exclusive federal matters that do not (considerably) affect sub-state policy. The territorial representation function requires the strongest say in matters under category one and no or only weak involvement in matters under category four. In reality, the Upper Houses' packages of competences are indeed differentiated, although not necessarily according to this fourfold arrangement.

\section{Practice}

In practice, not all Upper Houses in bicameral federal states fulfil these requirements, making the correlation between federalism and bicameralism quite misleading. Reasons are manifold, including historical path dependence, democracy concerns and efficiency arguments (Palermo and Kössler 2017: 148). An example is Spain, where the Upper House is not representative of the Self-Governing Communities and only has a suspensory vote (Art 90 Spanish Constitution; Ferreres Comella 2013: 96-97; Palermo and Kössler 2017: 144). In Canada as well, Senators are not representative of the states, to the point that the Upper House has been labelled 'a case of pseudo-bicameralism' (Hueglin and Fenna 2006: 190). The Belgian case constitutes another illustration: after the 1993 reform, the sub-states were only partially represented. Since 2014, the Upper House has become a Chamber of the sub-states, but its remaining powers almost exclusively belong to category one.

The conclusion is that there is no necessary link between federalism and bicameralism (Sharman 1987: 96). In some federal systems, there is no Upper House at all. This is the case in very small federations such as Micronesia and St. Kitts and Nevis, but also in larger federal systems such as Venezuela. Interestingly, in Venezuela, a process aimed at reinforcing the federal system resulted in the abolishment of bicameralism, as the Upper House was perceived as bastion for traditional, centralised parties suspected of withholding institutional reform (Penfold-Becerra 2004:219). The Venice Commission even pleaded for the abolishment of the Upper House in Bosnia and Herzegovina, where only Bosnians, Croats and Serbs are represented, with important veto powers, to the exclusion of other groups in society (Venice Commission 2005, \36). Instead, other mechanisms may fulfil the function of territorial representation. 
One option is representation of the sub-states within a single chamber. For example, in Micronesia, Congress consists of one member elected at large from each state on the basis of state equality, and additional members are elected in each state apportioned by population (Art. 8 Micronesian Constitution). In Venezuela, each state elects three representatives, in addition to the directly elected Deputies (Art. 186 Venezuelan Constitution). Such was also the proposition of the Venice Commission regarding Bosnia and Herzegovina (Venice Commission 2005: \36). Interestingly, with devolution in the $\mathrm{UK}$, the need for territorial representation led to a differentiation of matters in the House of Commons legislative procedures (English Votes for English Laws), rather than a reform of the House of Lords (see Guastaferro 2018).

Another possibility is direct involvement of the sub-states; the Belgian case is an example. First, the Special Majority Law (Special Law 8 August 1980 on the reform of institutions) enumerates specific matters in which the federal legislature is under obligation to consult or negotiate with the sub-states, or to conclude inter-federal cooperation agreements. Second, all legislative assemblies have the power to intervene directly in the federal (and other sub-state's) parliamentary procedures, and suspend the procedure for further negotiations if they consider that a pending bill may seriously harm their interests (Art. 32 Special Law 8 August 1980 on the reform of institutions). The drawback of the latter system is that bills are not systematically seen by regional parliaments. Also, this mechanism corresponds to a conflict model, whereas the involvement of the Senate takes place in a more harmonious model. Therefore, Upper Houses are better suited to balanced federal systems, whereas direct sub-state interference is more indicative of a confederal system.

\subsection{Sub-state involvement in external matters}

The entanglement of states in international or supranational networks impacts on the position of sub-states in federations, as sub-state competences are also exercised at the international and, in particular, the EU level. It is vital, then, for sub-states to be involved in international and supranational rule-making in matters that affect their competences. For parliaments, this concerns, amongst others, the approval of treaties, participation in the EU Early Warning System and the standpoint the executive is to take in the Council of Ministers. 
States can take three approaches: a centralist approach, a gate-keeper approach and a dual approach (see further Popelier 2014: 10-12). In the first approach, the central government is in control, which fits best in more regionalised multi-tiered systems. In the gate-keeper approach, the central government is the main point of contact, but sub-states are involved in the determination of the state's position. They have most impact when they act not in isolation but in unison with other sub-states. This is a more balanced approach, and therefore the most likely to be found in federal systems. Lastly, in a dual approach, sub-states have wide powers to establish external relations, including the right to conclude international agreements without the Federal Government's consent; they have direct representation within the Council of Ministers, and individual sub-states can veto 'mixed' treaties negotiated by the central government. In this approach, the interests of individual sub-states are given more weight than the collective will of the sub-states.

For systems that prefer a federalist gate-keeper approach, Upper Houses, composed as Chambers of the sub-states, are an ideal match. For example, in Germany, treaty revisions that involve the delegation of powers to the EU requires a two third majority in both the Bundestag and the Bundesrat (Art. 23(1) combined with Art. 79(2) Basic Law). Art. 23 Basic Law secures the right of the Bundesrat to be involved in determining the Federal Government's position in EU Affairs, according to the Länder interests involved.

\subsection{Checks and balances}

Bicameral systems, in both multi-tiered and unitary systems, are often justified as instruments of checks and balances: they reduce the concentration of power in one House, and confine executive's powers because two Houses are allegedly more difficult to manipulate (Trivelli 1974: 29). In practice, the dilemma mentioned above made it difficult for Upper Houses to fulfil this task: if specific but not representative, they have no legitimacy for curbing decisions of the Lower Houses; if representative but not specific they will reach the same conclusions. The latter is especially the case in parliamentary systems, where the Executive emanates from the majority in Parliament.

This function, however, gains relevance in federal systems. As mentioned, federalism allows for the combination of specificity and representativeness. Moreover, the idea of curtailing government power is a basic principle on which federal theories are built (Burgess 2006: 35), which explains the notable correlation of bicameralism and federal 
systems (Sharman 1987: 96). Nonetheless, the function presupposes strong Upper Houses, which is more likely in presidential systems rather than parliamentary systems. Germany, Australia and Switzerland are rare examples of strong Upper Houses in parliamentary systems (Stone 2003: 1; Swenden 2010: 106). In other parliamentary systems, alternative mechanisms of checks and balances, such as judicial review, can compensate for weak Upper Houses.

\subsection{Multinational conflict management}

Multinational states are often divided. Any state contains groups that differentiate themselves through language, religion or ethnic background. In divided societies, however, these group features are essential for shaping identity, political mobilisation and structural political conflicts (Choudhry and Hume 2011: 363). They are called 'multinational states' if such groups are localised within one territory and claim self-governance on the basis of national identity (Stepan 2004).

Federalism can serve as a solution to keep the state together while giving national groups space to develop diversity (Hueglin and Fenna 2006: 24). Whether federal or not, central governments are advised to involve national groups in central decision making that affects their interests. This reduces the risk that central decisions have a negative impact on these groups, causing them to react against the system and threatening the state's integrity (Choudhry and Hume 2011: 375; Lantscher, Constantin, Kmezic and Marko 2012: 277278; McGarry and O'Leary 2005: 282). Thus, representation of national sub-groups at the central level is vital for the survival of divided states (Osoghae 1998: 203). Representation can also take place in a unicameral system, whether federal or not, through several mechanisms, such as the exemption from an electoral threshold for parties that represent national minorities; the delineation of electoral districts; or the allocation of a number of seats to representatives of national minorities (Lantschner and Kmezic 2012: 235-236). In federal systems, Upper Houses are the most obvious forum for this function. In practice, however, Upper Houses in divided societies are often unable to fulfil their task, because of their composition or limited powers. According to Osoghae (1998: 210) this may be explained by the fear that strong multinational mechanisms reinforce identity awareness to the point that decentralist dynamics get out of hand. 


\subsection{Conclusion}

While federalism and bicameralism are often correlated, Upper Houses are not essential for a federal system. More important is the function that is assigned to Upper Houses. In federal systems, the most common - but not necessarily exclusive - function is representation of territorial sub-entities. To fulfil this task, however, Upper Houses have to fulfil certain requirements that concern both composition and competences. Where these conditions are not fulfilled, alternative mechanisms may secure the involvement of substates in central decision making. Such mechanisms may favour the protection of individual sub-state interests over the protection of collective interests. In multinational states, the representation of national groups is vital for the survival of the system. Therefore, where national groups do not entirely match with territorial division, representation of national groups will have priority over representation of territorial sub-entities.

These findings will guide the discussion of the puzzle with which Section one of this paper concluded, and which is resumed in the following Section. The central position is that multinationalism explains why bicameralism is being gradually dismantled in Belgium, despite continuous decentralising dynamics.

\section{The dismantling of the Belgian Senate as a symbol of multinational confederalism}

\subsection{Introduction}

According to parliamentary documents, the main purpose of Senate reform was securing the involvement of the territorial sub-states (Parl.Doc. Senate 2011-2012, 51720/1: 2). This explains why - apart from the relic of co-opted senators - the Senate is composed of members of the sub-state assemblies. However, it neither explains the complexity of its rules of composition, nor its declining powers.

Confederalist aspirations, as a device for multinational conflict management, provide more insight in the peculiarities of the Belgian Senate. As mentioned above, in the search for an optimum between diversity and integrity, confederal systems prefer the maximisation of diversity. Belgium is a federal system with undeniable confederal traits, as federal decisions require the approval of the two major language groups: language parity in the federal government ensures that any government decision is approved by both 
language groups and in Parliament each language group has a veto right with regard to special majority laws.

Multinationalism coincides with the delineation of sub-states, but only partially. The division of territorial Communities and Regions is complex, due to diverging views on whether the federal design should be Community-based or Region-based. The Walloons aspired for autonomy with regard to territory-based competences such as economic policy, whereas the Flemish demanded autonomy with regard to cultural and other languagerelated matters. The Walloon demand led to the creation of three Regions: a Flemish, a Walloon and a Brussels Region. The Flemish demand led to the creation of Communities, with a German-speaking Community that was given far-reaching autonomy considering that the unit represents less than 1\% of the population, and with a French-speaking and a Flemish Community that both have competences in Brussels, because of the bilingual status of Brussels. Within Brussels, two extra Communities emerged, one (the Joint Community Commission) to deal with certain matters regarding Brussels residents and bilingual institutions; another (the French Community Commission) to take over competences transferred by the French-speaking Community to the Walloon Region, as the latter has no powers in Brussels. On the Flemish side, the Community and Region institutions have merged. The result is an overlap of institutions with different sets of competences.

At the heart, however, everything revolves around the two major language groups, the French and the Dutch. In what follows, I will demonstrate that 1) territorial representation must not interfere with power relations between the major language groups and 2) in accordance with confederalism, individual veto power was preferred over collective involvement.

\subsection{Preference for language groups over territorial representation}

The Senate is composed of MPs of the sub-national assemblies, yet the partitioning in two language groups has not been removed. The representation of the sub-states was not to interfere with the proportional share of each language group. Territorial representation threatened to do so, as there are more French-speaking sub-states compared to Dutchspeaking sub-states: on the Flemish side, because of the merger of the Community and Regional levels, there is only one sub-state entity, whereas on the francophone side, the 
French-speaking Community and the Walloon Region are accompanied by the bilingual but mainly francophone Brussels Region. Hence, as was clarified in the parliamentary debate, the composition of the Senate was not the result of common negotiations; instead each language group was allocated a specific number of seats - apart from the co-opted senators: 29 for the Dutch language group, 20 for the French language group - and each group was to decide for itself how to fit sub-state representation within that portion (Parl. Reports Plenary Session, Senate 2013-2014, 5-125: 26 November 2013 - afternoon).

On the Flemish side, this was relatively simple, since the Flemish Parliament is representative of both the Region and the Community. The only concern was to also involve the Dutch-speaking members of the Brussels Region. For the French-speaking side, the concern to find a compromise between 'regionalists' and 'communitarists', together with the involvement of the Brussels Region, resulted in more complexity. Moreover, the division in language groups and the discussions per language group explain why, ultimately, the Brussels Region is not, as such, represented in the Senate. Instead, the language groups within the Parliament of the Brussels Region are represented. On the Flemish side, the representatives are appointed by the Flemish Parliament from within that Parliament or the Dutch-speaking language group of the Brussels Parliament. For the francophones, two senators are appointed by the French language group of the Brussels Parliament from its members, and three out of ten senators appointed by the French Community must (also) ${ }^{\mathrm{III}}$ be a member of the French language group of the Brussels Parliament. As a result, the language groups, not the Brussels Parliament as such, are represented in the Senate. This makes sense for the French language group in the Brussels Parliament, as this constitutes a separate autonomous entity, for the few competences that have been given up by the French Community and transferred to the Walloon Region on the one hand and, for Brussels, the French language group in the Brussels Parliament on the other. By contrast, the Dutch language group of the Brussels Parliament is a separate entity with administrative powers under the hierarchy of the Flemish Community, not an autonomous sub-state.

\subsection{Preference for confederal over federal arrangements}

Confederalism is mainly concerned with the preservation of autonomy of the entities in the confederation, that are considered equal within the confederal entity. Therefore, 
confederal authority requires the approval of the constituent entities, and each constituent entity has the individual power to interfere with or obstruct the confederal decision-making process.

In Belgium, confederal traits mainly relate to the language groups. As language groups and sub-states coincide in many regards, this is intensified by mechanisms that allow direct involvement of individual sub-states. For example, each sub-state Parliament can interfere in the federal law-making process and adjourn the procedure for negotiations (Art. 143 \ 3 Constitution and Art. 32 Ordinary Law on the Reform of Institutions of 9 August 1980). This compensates for the drastically reduced powers of the Senate. 'Mixed' international treaties, combining federal and sub-state matters, require the approval of federal and substate parliaments, thereby giving each parliament a veto right. Instead of reducing this veto right, which, as the CETA adventures showed, ${ }^{\text {IV }}$ risks undermining federal external policy, the Senate's power to give approval to international treaties was removed. Clearly, direct and individual involvement was preferred over a more balanced, indirect and collective involvement through the Chamber of sub-states.

Only two political parties explicitly aspire towards confederalism: the Flemish Christian-Democrat party sees it as the ideal state structure for Belgium; the separatist Flemish party N-VA considers it a transition phase towards the disappearance of the Belgian state. Although the N-VA withdrew from the negotiations for the sixth state reform, confederalist aspirations seem to have impacted deeply on the final result.

Still, one could wonder why the Upper House was not valued more in a combination with direct involvement. Indeed, the mechanism for direct involvement in the federal lawmaking procedure is far from effective: sub-states are not systematically informed of the bills and proposals handled by the Chamber of Representatives; and if negotiations do not lead to a compromise, the Chamber can resume the procedure. Consequently, confederalists would be expected to prefer the Chamber of sub-states over the Chamber of Representatives. However, in Belgium, the powers of the Chamber of Representatives have been strengthened to the detriment of the Senate.

The answer is that the Chamber of Representatives is not a federal chamber that represents the federal interests. It is composed of representatives of the two language communities, elected on lists adopted by regionally-based political parties, divided in two language groups, and constituting a majority to support a government that, in conformity 
with the constitution, is made up of an equal number of French- and Dutch-speaking ministers.

Consequently, where language group representation is preferred over territorial representation and confederalist decision making is preferred over the federalist, the Chamber of Representatives is the preferential chamber.

\section{Conclusion}

The research question was phrased as follows: 'how does the dismantling of the Belgian Senate fit in the increasingly devolutionary nature of the Belgian state structure?'.

Section 1 showed the gradual dismantling of the Senate: as it was turned into a more genuine chamber of the sub-states, it was deprived of most of its powers. Section 2 clarified the various functions of Upper Houses in multi-tiered systems, and the requirements regarding composition and competences needed to fulfil these functions. It highlighted that while bicameralism is the preferred institutional device for federal states, it is not essential. Section 3 applied this to the Belgian Senate. While, officially, the function of the Senate is territorial representation, it is imperfect as to composition and inadequate as to competences. It has no function in external relations, having lost its powers to give approval to international agreements. It is inadequate in its provision for checks and balances; the system has turned into a de facto unicameral one, except in important but exceptional institutional and constitutional matters. What remains is its function as management tool for multinational conflict. For this function, language group representation is preferred over sub-state representation. This explains the complex composition of the Senate, but also explains the preference for the Chamber of Representatives over the Senate.

Multinationalism-based confederalism, then, is the answer to the research question. The transformation of the Senate into a Chamber of the sub-states turned out to be an inadequate effort to disguise how the Belgian state increasingly evolves towards confederalism based on two major linguistic groups.

\footnotetext{
* Professor of Constitutional Law, University of Antwerp.

II Art. 56, $4^{\circ}$ and $5^{\circ}$ Constitution in the 1831 version. Originally, the Senators also had a mandate of 8 years instead of four.

II Along with a large population, size and the presence of a stable democracy, i.e. the absence of a coup or
} 
revolution leading to the abolishment of traditional institutions (Massicotte 2001: 152).

III At least two must also be a member of the French-speaking Community Parliament, one of them does not. The French- speaking Community Parliament is not directly elected, but composed of all 75 members of the Parliament of the Walloon Region and 19 out of 72 French-speaking members of the Brussels Parliament. This is different in Flanders, where the Flemish Parliament is directly elected and the members of the Dutchspeaking language group have no institutional link with the Flemish Parliament.

IV A trade agreement between the EU and Canada was temporarily obstructed because the EU required approval of all Member States, which means, in Belgium, that every sub-state has to approve. The francophone socialists, at the time in power in the Walloon Region and the Brussels Region but excluded from the federal coalition, threatened to veto the agreement.

\section{References}

- $\quad$ Alen André, 1992, 'Le bicaméralisme belge, de la voie unitaire à la voie fédérale', in 439-46.

- Bogdanor Vernon, 1992, 'The problem of the upper house', in Blom H.W., Blockmans Willem Pieter and De Schepper Hugo (eds), Bicameralisme, SdU Publisher, 's Gravenhage, 411-422.

- $\quad$ Burgess Michael, 2006, Comparative federalism. Theory and Practice, Routledge, London.

- Choudhry Sujit and Hume Nathan, 2011, 'Federalism, devolution and secession: from classical to post-conflict federalism', in Ginsburg Tom and Dixon Rosalind (eds), Comparative Constitutional Law, Edward Elgar, Cheltenham, 356-384.

- De Schepper Hugo, 1990, 'De Eerste Kamer in het Verenigd Koninkrijk der Nederlanden', in Postma A., De Rijk L.M., Sprey A., Vis J.J. and van der Werff Y:P.W. (eds.), Aan deze zijde van het Binnenhof. Gedenkboek ter gelegenheid van het 175-jarig bestaan van de Eerste Kamer der Staten-Generaal, SdU, 's Gravenhage, 16-31.

- $\quad$ Ferreres Comella Víctor, 2013, The Constitution of Spain: A contextual analysis, Hart Publishing, Oxford.

- Goossens Charles, 1983, 'Le bicaméralisme en Belgique et son évolution', in Liber Amicorum F. Dumon, Kluwer, Antwerp, 793-872.

- Guastaferro Barbara, 2018, "Visible" and "Invisible" Second Chambers in Unitary States “Territorialising” National Legislatures in Italy and the United Kingdom', in Fasone Cristina (ed), Bicameralism under Pressure: Constitutional Reform of National Legislatures, Edward Elgar Publishing Cheltenham (in press).

- Hueglin Thomas and Fenna Alan, 2006, Comparative Federalism. A Systematic Inquiry, Broadview Press, Toronto.

- Huyttens Emile, 1844, Discussions du Congrès National de Belgique, A. Wahlen,, Bruxelles, part I.

- Lantschner Emma, Constantin Sergiu, Kmezic Marko and Marko Joseph, 2012, 'Comparative Conclusions', in Lantschner Emma, Constantin Sergiu and Marko Joseph (eds), Practice of Minority Protection in Central Europe, Nomos, Baden-Baden, 261-278.

- Lantschner Emma and Kmezic Marko, 'Political Participation of Minorities in Central Europe: Is it Effective or Just Window-Dressing?', in Lantschner Emma, Constantin Sergiu and Marko Joseph (eds), Practice of Minority Protection in Central Europe, Nomos, Baden-Baden, 223-260.

- $\quad$ Luyckx Theo and Platel Marc, 1985, Politieke geschiedenis van België, Kluwer, Antwerp.

- Massicotte Louis, 2001, 'Legislative Unicameralism: A Global Survey and a Few Case Studies', The Journal of Legislative Studies, VII(1): 151-170.

- Mastias Jean and Grange Jean, 1987, Les seconds chambres du parlement en Europe occidentale, Economica, Paris.

- McGarry John and O'Leary Brendan, 2005, 'Federation as a Method of Ethnic Conflict Regulation', in Noel Sid (ed), From power-sharing to democracy: post-conflict institutions in ethnically divided societies, McGill Queen's Press, Montreal, 263-296.

- Osoghae Eghosa E., 1998, 'Purpose and functioning of the Senate', in De Villiers Bertus, Delmartino Frank and Alen André (eds), Institutional Development in Divided Societies, Human Rights Research Council, Pretoria, 219-220.

- Palermo Francesco and Kössler Karl, 2017, Comparative Federalism. Institutional Arrangements and Case Law, Hart Publishing, Oxford. 
- Penfold-Becerra, 2004, 'Federalism and Institutional Change in Venezuela', in E. Gibson (ed) Federalism and Democracy in Latin America (Baltimore, The John Hopkin University Press): 197-225

- $\quad$ Popelier Patricia, 2014, 'Subnational multilevel constitutionalism', Perspectives of Federalism, VI(2): 1-23.

- Popelier Patricia and Lemmens Koen, 2016, The Constitution of Belgium - A Contextual Analysis, Hart Publishing, Oxford.

- Popelier Patricia and Vandenbruwaene Werner, 2011, 'The Subsidiarity Mechanism as a Tool for Inter-Level Dialogue in Belgium: on 'Regional Blindness' and Cooperative Flaws', European Constitutional Law Review, VII(2): 204-228.

- $\quad$ Russell Meg, 2000, Reforming the House of Lords: Lessons from Overseas, Oxford University Press, Oxford.

- Sharman Campbell, 1987, 'Second Chamber', in Bakvis Herman and Chandler William M. (eds), Federalism and the role of the State, University of Toronto Press, Toronto, 57-81.

- Stengers Jean, 1990, 'Les caractères généraux de l'évolution du Sénat depuis 1831', in La réforme du Sénat, Bruylant, Brussels, 13-43.

- Stepan Alfreed, 2004, 'A New Comparative Politics of Federalism', in Gibson Edward L. (ed), Federalism and Democracy in Latin America, The John Hopkins University Press, Baltimore, Maryland, 29-84.

- Stone Bruce, 2003, 'Australian Bicameralism: Potential and Performance in State Upper Houses', Papers on Parliament No. 41.

- Swenden, Wilfried, 2010, 'Subnational participation in national decisions: the role of second chambers', in Enderlein Henrik, Wälti Sonja and Zürn Michael (eds), Handbook on Multi-Level Governanc, Edwar Elgar, Cheltenham, 114-117.

- Trivelli Laurent, 1974, Le bicaméralisme. Institutions comparées, Imprimerie Pont Frères, Lausanne.

- Venice Commission: European Commission for democracy through law, 2005, Opinion on the constitutional situation in Bosnia and Herregovina and the powers of the High Representative, CDL-AD (2005) 004, 11 March 2005, para. 36.

- Watts Ronald, 2003, 'Bicameralism in Federal Systems', in Joyal Serge (ed), Protecting Canadian Democracy: The Senate You Never Knew, Mc Gill Queen's Press, Montreal, 67-104. 